ILLUSION OF CONSENT 


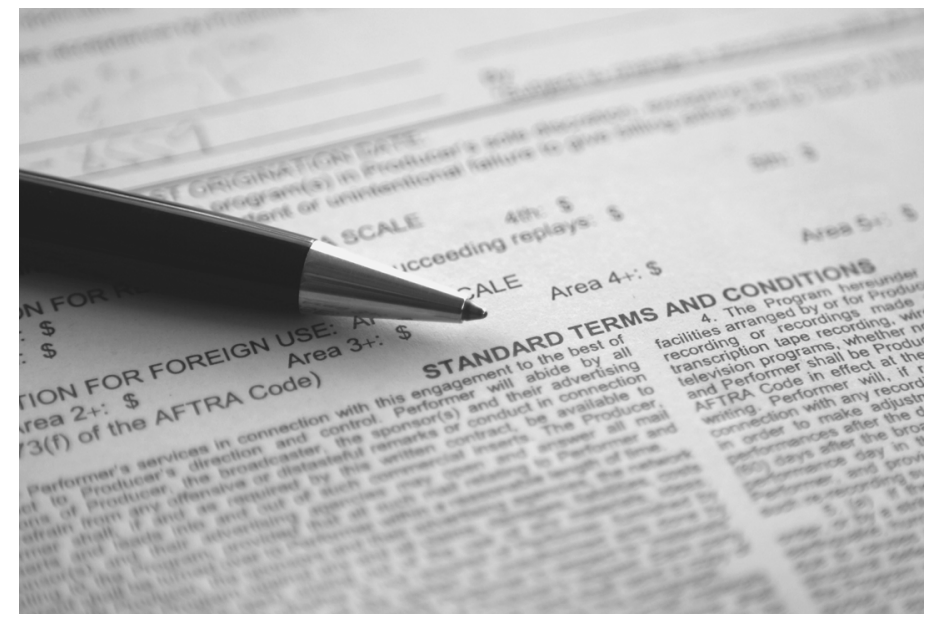




\title{
ILLUSION OF CONSENT
}

\author{
ENG AGING \\ WITH \\ CAROLE PATEMAN
}

Edited by Daniel I. O’Neill, Mary Lyndon Shanley, and Iris Marion Young

The Pennsylvania State University Press

University Park, Pennsylvania 


\section{Library of Congress Cataloging-in-Publication Data}

Illusion of consent : engaging with Carole Pateman / edited by Daniel I. O’Neill,

Mary Lyndon Shanley, and Iris Marion Young.

p. $\quad \mathrm{cm}$.

Includes bibliographical references and index.

Summary: "A collection of essays that discuss the writings of Carole Pateman, with emphasis on her theories of democracy and feminism"-Provided by publisher.

ISBN 978-0-271-03351-8 (cloth : alk. paper)

1. Democracy.

2. Liberalism.

3. Feminist theory.

4. Social contract.

5. Pateman, Carole.

I. O’Neill, Daniel I., 1967- .

II. Shanley, Mary Lyndon, 1944- .

III. Young, Iris Marion, 1949- .

JC423.I43 2008

$321.8-\mathrm{dc} 22$

2007050226

Copyright (C) 2008 The Pennsylvania State University

All rights reserved

Printed in the United States of America

Published by The Pennsylvania State University Press,

University Park, PA 16802-1003

The Pennsylvania State University Press is a member of the Association of American University Presses.

It is the policy of The Pennsylvania State University Press to use acid-free paper. This book is printed on Natures Natural, containing $50 \%$ post-consumer waste, and meets the minimum requirements of American National Standard for Information Sciences-

Permanence of Paper for Printed Library Material, ANsi z39.48-1992. 